УДК: 94(477) «1919 - 1939»

ВИЗДРИК В.С.

МЕЛЬНИК О.М.

\title{
ДЕЯКІ ОСОБЛИВОСТІ КОЛОНІЗАЦІЙНОЇ ПОЛІТИКИ ПОЛЬЩІ НА ЗАХІДНОУКРАЇНСЬКИХ ЗЕМЛЯХ У МІЖВОСННИЙ ПЕРІОД: НОРМАТИВНО-ПРАВОВА БАЗА
}

У статті проаналізовано нормативно-правову базу урядової аграрної політики Польщі в Західній Україні в міжвоєнний період. Досліджується проведення польської сільськогосподарської колонізації, що загострила соціальні та національні протиріччя між українським й польським населенням краю. Планомірна осадницька колонізація передбачала переселення з етнічних польських земель військових осадників і цивільних колоністів та створення ними фермерських господарств уздовж польсько-радянського кордону, що мали стати соціальною опорою політики уряду на східних і південно-східних окраїнах Польщі.

Ключові слова: нормативно-правова база, міжвоєнний період, військові осадники, цивільні колоністи, Західна Україна, колонізація.

Актуальність та постановка проблеми. Соціально-економічні відносини в Західній Україні у міжвоєнний період потребують вивчення та узагальнення, оскільки були проблемою не тільки економічною, а й політичною. Колонізація західноукраїнських земель була проголошена офіційним курсом держави. Досвід розвитку ринкових відносин на селі, вимагає всебічного аналізу всієї соціально-економічної структури галицько-волинського села. Дане дослідження зумовлюється не тільки пізнавальною необхідністю, а й практичними потребами вивчення історичного досвіду реформування аграрних відносин та розвитку міжнаціональних стосунків.

Виздрик Віталій Степанович, доктор історичних наук, доцент, професор кафедри гуманітарних наук Інституту морально-психологічного забезпечення Національної академії сухопутних військ імені гетьмана Петра Сагайдачного, м. Львів.

Мельник Олександра Михайлівна, кандидат економічних наук, доцент, доцент кафедри гуманітарних наук Інституту морально-психологічного забезпечення Національної академії сухопутних військ імені гетьмана Петра Сагайдачного, м. .Львів.

() Виздрик В.С., Мельник О.М., 2018. 
Метою дослідження є спроба проаналізувати нормативноправову базу та основні етапи впровадження аграрної реформи, складовою частиною якої була польська сільськогосподарська колонізація.

Огляд літератури $i$ джерел. Актуальні питання соціальноекономічних та політичних перетворень у добу міжвоєнної Польщі містять дослідження як українських істориків, наприклад, I. Васюти, Л. Зашкільняка, М. Крикуна, І. Зуляк, В. Комара, I. Крюкова [1], так і польських науковців - М. Боруцького, П. Вечоркевича, А. Єзерського і С. Лещиньської, Я. Калінського і 3. Ландау, Й. Столбняк-Смогоржевської, Р. Торжецького [2].

Виклад основного матеріалу та обтрунтування отриманих результатів дослідження. Перед відродженою Польщею постав комплекс проблем з розбудови власної національної державності. Тому першочерговим завданням у процесі політичного та економічного становлення Польської держави у міжвоєнний період було реформування аграрної системи. "Польське суспільство $є$ аграрним і всі програми його розвитку повинні виходити 3 питання впорядкування аграрного устрою", - наголошував польський історик та правознавець В. Яворський [16, s. 6]. Це мало забезпечити не лише піднесення сільськогосподарського виробництва, а й відродження на цій основі промисловості та досягнення економічної, соціальної та політичної стабільності загалом [8, с. 467].

У листопаді 1918 р. було видано маніфест, що проголошував примусову ліквідацію великої і середньої земельної власності. Під тиском селянського невдоволення та політичних партій уряд I. Падеревського змушений був у червні 1919 р. внести на розгляд сейму проект земельної реформи, навколо якого в сеймі точилась гостра боротьба між основними політичними угрупованнями. Нарешті, 10 липня 1919 р. переважно голосами депутатів соціалреформістських партій, сейм ухвалив проект "Основ земельної реформи", запропонований правою селянською партією ПСЛ "П'яст". Цей правовий акт польського сейму передбачав насамперед пришвидшення процесу становлення і зміцнення фермерського (селянського) господарства задля створення у Польщі такого аграрного устрою, який "повинен спиратися в першу чергу на сильних, здорових і здатних до інтенсивного 
виробництва селянських господарствах, що грунтуються на приватній власності різного типу і величини" [17, s. 29; 18 , s. 135]. Цей законодавчий акт також визначив колонізацію як основний напрям аграрних перетворень.

Урядова ухвала оберігала інтереси поміщиків, містила “виняткові положення", спрямовані на колонізацію українських земель та полонізацію українців. Нею передбачалося щорічне парцелювання (продаж землі парцелами - невеликими наділами) державою 200 тис. га земель державних, військових спекулянтів, занедбаних маєтків і лише в останню чергу - поміщицьких господарств. При цьому були свої особливості при викупі та парцеляції частини поміщицьких маєтків, що перевищували максимум володіння землею: якщо в Галичині цей розмір становив 180 га, то для Східної Галичини, де жили етнічні українці, - 400 га. [7; с. 215; 9, с. 41]. За відчуження земель понад норму встановлювався високий викуп, який держава оплачувала ïх власникам. 3 цих земель створювався державний земельний фонд, призначений для парцеляції $\mathrm{i}$ продажу відповідним категоріям набувачів.

Господарства промислово-підприємницького типу, а також маєтки, що спеціалізувались на насінництві, тваринництві i риболовстві, незалежно від їх площі звільнялися від обов'язкового викупу. Недоторканними залишались маєтки церкви i монастирів, що тримали у своїх руках великі земельні площі. Уряд не посмів і не хотів посягати на економічну основу католицького духовенства. Питання про відчуження маєтків "мертвої руки" для парцеляції у кожному конкретному випадку підлягало погодженню з Ватиканом [17, s. 30].

3 державного парцеляційного фонду понад 20\% землі (а незабаром після зміни уряду цю норму збільшено до 40\%) призначалося на створення фермерських господарств. Усі інші землі 3 цього фонду виділялися для сільськогосподарських робітників і малоземельних селян. Однак право придбання землі проголошувалося фактично тільки на папері, згідно з "Основами земельної реформи", власником землі могла бути лише та особа, яка спроможна організувати самостійне господарство. Якщо заможним селянам реформа відкривала великі можливості для зміцнення своїх господарств, то незаможні верстви, що терпіли від безземелля і малоземелля, вона фактично нічого не давала. 
Проте, закон від 10 липня 1919 р. не набув сили обов’язкового виконання, оскільки не був опублікований у "Dziennik ustaw Rzeczypospolitej Polskiej”.

Протягом 1919 - 1920 років у фонд держави перейшло всього 576,5 тис. га так званих "безгосподарних" та інших земель, а розпарцельовано і продано дрібним власникам Польщі тільки 50 тис. га [19, s. 49], це свідчить, що державна парцеляція проводилась у незначних розмірах. 3 метою контролю за перебігом парцеляційного процесу був утворений Земельний національний суд, який пильнував за тим, щоб земля потрапляла у володіння польських власників [4, с. 5].

Отже, земельна реформа, основи якої сейм затвердив, щоб запобігти селянським заворушенням, давала лише невиразні обіцянки ліквідувати земельний голод. Цим політичні кола i влада розраховували посіяти ілюзії про розв'язання аграрного питання легітимними засобами, щоб паралізувати радикально налаштоване українське село.

Загострення політичної та військової ситуації на польськорадянському фронті в липні 1920 р., змусила польський сейм поспіхом прийняти виконавчі правила до основ земельної реформи, котрі також значною мірою мали декларативний характер [12, s. 21]. Закон "Про виконання земельної реформи" 1920 р. був сформульований радикальніше, ніж сеймова ухвала 1919 р.. За ним збільшувалась кількість землі, що підлягала відчуженню i призначалась на парцеляцію й осадництво. Поміщицькі і церковні землі, що перевищували максимальну норму, повинні були викуповуватись за половину їхньої середньо ринкової ціни, їх живий і мертвий інвентар також підлягав примусовому викупу. Згідно 3 новим законом, заможні селяни могли створювати самостійні господарства до 15 га або ж докуповувати землю 3 такою умовою, щоб розмір їхніх господарств не перевищував 23 га, а в східних і західних воєводствах - 45 га [13, s. 1230-1233].

Урядова ухвала визначала структуру виконавчих органів із впровадження аграрної реформи [15, s. 11]. Центральним органом стала Головна земельна управа (з 1923 р. - Міністерство аграрних реформ). На місцях утворювались окружні земельні воєводські та повітові управління й комісії, до функцій яких входили 
підготовка i проведення заходів, пов'язаних із перебудовою земельного устрою: розробка проектів законів, контроль за парцеляцією та колонізацією, координування діяльності Державного сільськогосподарського банку тощо [11, s. 131].

Уже 17 грудня 1920 р. польський уряд прийняв закон про військову колонізацію, який передбачав, що власністю держави ставали всі колишні землеволодіння царської Росії в цьому регіоні, а також так звані безгосподарні землі приватних власників. Особливістю цього закону було те, що $80 \%$ запасу землі призначалося для наділення безземельних і малоземельних селян, однак перевага при цьому надавалась інвалідам і солдатам польської армії, особливо фронтовикам і добровольцям учасникам воєн 1918 - 1920 років. Цього права позбавлялися дезертири і учасники революційного руху, які боролися або виступали проти польської держави. Закон був спрямований проти радикальних елементів села, які позбавлялися можливості придбати землю. Населення Західної України не вважалося громадянами польської держави і практично позбавлялися права на придбання землі, а етнічні землі українців стали об'єктом інтенсивної польської колонізації. Військові осадники мають право безкоштовно отримати до 45 га землі із державного фонду на Волині, Віленщині й у Західній Білорусії. Ці новостворені господарства не можна було ні продавати, ні передавати іншим особам без дозволу уряду протягом 25 років. Передбачалося надання колоністам, передусім військовим, безкоштовних державних субсидій та допомога інвентарем, насінням, будматеріалами [22, s. 81]. Створювалися повітові комітети для забезпечення землею військових колоністів, куди входили повітовий староста або його заступник, представники від Міністерства землеробства й аграрних реформ, Міністерства фінансів, Міністерства військових справ, а також від місцевих землевласників.

Польський уряд отримав в особі військових колоністів найбільш надійних кадрів польської колонізації. Привілейованість осадників проявлялася у зверхньому ставленні до корінного українського населення, вважаючи себе представниками «вищої культури». Усіма справами самоврядування військових осадників займався Центральний союз військових осадників, а на місцях воєводські та повітові союзи. Користуючись постійною підтримкою 
влади військові осадники та заможні цивільні колоністи були спроможні вести господарство фермерського типу. 3 їх числа призначалися солтиси, війти та інші представники державної влади на місцях.

Протягом 1921 - 1925 років у Польщі було розпарцельовано всього 690 тис. га (5\% площі великих землевласників), з них менше третини припадало на державну парцеляцію, що охоплювала тільки $10 \%$ площі державних площ. У той же час поміщики збули 3 великою вигодою 472 тис. га гіршої землі шляхом приватної парцеляції [19, s. 49]. Принцип примусового відчуження землі не застосовувався навіть до тих маєтків, землі яких більшою або меншою мірою здавалися в оренду. Самі ж польські селяни, за винятком незначної кількості військових осадників на Західній Україні, не одержали без винагороди жодного гектара землі. Окремі ділянки землі, які парцелювали та продавали самі поміщики або земельні управління, дісталися здебільшого заможній верхівці села. Все це викликало невдоволення та справедливий протест незаможних верств селянства, які стали ще наполегливіше вимагати конфіскації та розподілу поміщицьких земель.

Земельна реформа і пов'язане 3 нею польське осадництво вкрай загострили національні і соціальні протиріччя в суспільстві. Завдання уряду полягали в зміні кількісного співвідношення українського та польського населення на користь останнього за рахунок переселення 3 польської етнічної території в Західну Україну. Колонізація була одним 3 важливих методів аграрної політики, адже польські осадники мали стати важливою соціальною та політичною опорою польської влади в Східній Галичині.

Реалізація законів 1919 і 1920 рр. в аграрному секторі відбувалися вкрай повільно, що змушувало шукати нових шляхів i підходів до його реформування. Зважаючи на складну політичну ситуацію у східних і південно-східних воєводствах, враховуючи вимоги політичних сил щодо реформування земельних відносин в інтересах селян, уряд В. Грабського 20 серпня 1925 р. провів новий закон під назвою “Про виконання аграрної реформи”, який вступав в дію з 28 грудня 1925 р [18, s. 487]. Він конкретизував положення двох попередніх законодавчих актів сейму в земельному питанні. 
Законом передбачалося:

1) створення нових самостійних господарств; 2) збільшення існуючих малоземельних господарств до розмірів самостійних; 3) створення дрібних господарств для виробництва городньоовочевої продукції; 4) створення приміських земельних ділянок для потреб робітників, службовців, інших категорій мешканців міст; 5) забезпечення необхідних умов для покращення системи господарської культури, зокрема сільськогосподарських шкіл, спеціалізованих товариств тощо [18, s. 488].

Щодо регулювання земельних відносин 3 католицькою церквою, то вони визначалися конкордатом, укладеним 18 лютого 1925 р. між Ватиканом і Польщею, згідно 3 яким польська держава гарантувала церкві різні дотації, остання ж погодилась на те, щоб частина іï земель була парцельована. Клір відстояв для себе високі норми землеволодіння: для капітулів, епіскопів і семінарій - 180 га, для приходів - 10 - 30 га [17, s. 117]. Усі інші церковні землі, якщо вони не підпадали під виключення за законом, як і маєтки великих світських землевласників, підлягали примусовому викупу державою.

Аграрна реформа виходила 3 економічної необхідності розчистити шлях для ринкового розвитку сільського господарства. Уряд обіцяв провести обов'язковий викуп частини приватновласницької землі вже не за половину середньої ринкової ціни, а за ціною, встановленою спеціальними державними комісіями. Проте за поміщиками залишалася попередня норма землеволодіння 3 тією лише різницею, що у східних воєводствах вона зменшувалася з 400 до 300 га [14, s. 3].

Реформа здійснювалась на основі добровільної парцеляції, яка хоча формально і контролювалась земельними управліннями, але фактично проводилась здебільшого самими поміщиками за ринковими цінами. В інтересах великих землевласників новий земельний закон включав до "обов'язкового викупу" і наступного продажу дрібними ділянками, по суті, лише землі, де велося нерентабельне господарство. Закон визначав норми і порядок проведення парцеляції, під яку потрапляли всі землеволодіння, що перевищували вказані граничні норми: приватні, церковні, державні, а також нерентабельні господарства. Водночас від парцеляції звільнялися: а) високопродуктивні спеціалізовані 
господарства 3 тваринництва, виробництва насіння, кормів тощо; б) лісові масиви, де велося промислове господарство; в) господарства, де вирощували технічні культури, зокрема картоплю (до 350 га), цукровий буряк (до 700 га) та ін. Встановлювався щорічний парцеляційний фонд (200 тис. га); якщо ж ця норма не виконувалася, то нерозпарцельовані землі включалися в план наступного року [3, с. 56]. Це свідчить про те, що реформа повинна була створити економічні умови для розвитку капіталістичних ринкових відносин у сільському господарстві.

Таким чином, обмежуючи великі землеволодіння, земельна реформа сприяла формуванню ринку землі та поглиблювала диференціацію селянських господарств.

Польський уряд надавав особливого значення проведенню аграрної політики на західноукраїнських землях. Виступаючи перед чиновниками окружного земельного управління у Львові міністр аграрних реформ Польщі В. Станєвич підкреслив, що "заможне, задоволене селянство на сході (в Західній Україні і Західній Білорусії) буде найліпшим оборонним валом, що захищає Польщу, а разом з нею і всю Західну Європу від гасел, проголошуваних на Сході" [21, s. 33]. Тому прагнув розширити i зміцнити задоволену режимом верству господарств фермерського типу i паралізувати вплив на сільську бідноту соціальноекономічних та політичних перетворень, які відбувалися в цей період у радянській Україні (НЕП, українізація).

За даними Міністерства сільського господарства і аграрних реформ Польщі, на початку 1919 р. в Західній Україні було 2 699,7 тис. га землі (у Східній Галичині - 1 550,7 тис. і на Волині 1149 тис. га) в тих маєтках, які мали у своєму володінні більше максимальної земельної норми, встановленої законом. Від обов'язкової парцеляції звільнялось 1523 тис. га найкращої землі, 56,5\% площі великих землеволодінь, головним чином лісових масивів, що мали промислову цінність, а також господарств промисловопідприємницького типу, маєтків з сільськогосподарською спеціалізацією та інших площ [3, с. 20].

Залежно від форми земельної власності визначалися механізми парцеляції: державна, банківська i приватна. Великі землевласники пускали в парцеляційний обіг гірші землі, на яких 
велось екстенсивне господарство. Для сприяння земельної реформи був створений у 1919 р. Державний сільськогосподарський банк, через який йшли кошти на виплату обов'язкового викупу тієї поміщицької землі, яка переходила у державний земельний фонд для парцеляції. Банк видавав також довгостроковий кредит особам, на яких, згідно із земельним законом, поширювалося право на придбання парцельованої землі. Сільськогосподарський банк мав право самостійно купувати приватні маєтки для проведення парцеляції, однак землевласникам було більш вигідно парцелювати землю без посередництва банку.

Частка держави і сільськогосподарського банку в парцеляційному обороті становила разом менше $0,6 \%$, а решту землі продали шляхом приватного розподілу самі власники маєтків або довірені ними юридичні особи - парцеляційні товариства і банки.

Приватну парцеляцію в Західній Україні проводили самі поміщики або акціонерні товариства та банки під наглядом земельних управлінь. У Східній Галичині парцеляцією землі займались Поміщицький кредитний банк, Аграрно-осадницьке товариство, Польське бюро парцеляційне, Парцеляційне товариство "Земля", Подільська спілка поміщиків, Парцеляційне товариство 'Толя", Дисконтний банк, Поміщицький банк для кресів, Товариство "Польська Глеба", Осадницько-парцеляційна спілка "Парцела", Народна парцеляційна спілка, Бюро обробітку землі та інші [5, арк. 1-4].

За ширмою парцеляційних товариств відбувалася шалена спекуляція землею. Після проведення грошової реформи 1924 р. ціни на землю різко зросли у порівнянні з довоєнним рівнем. Найбільше земельні ціни були роздуті поміщиками і спекулянтами в районах з гострим аграрним перенаселенням. Це стосується насамперед Галичини.

Великі землевласники використали парцеляцію, щоб за одержані кошти від іiі продажу ліквідувати свої заборгованості та раціоналізувати власні господарства, підняти свої маєтки із занепаду. Саме в 1921 - 1924 роках поміщики Східної Галичини продали половину розпарцельованих у міжвоєнний період земель краю. У парцеляційному обороті наступних років було все менше площі, в результаті чого ціни на землю невпинно зростали.

Державний сільськогосподарський банк у своїй діяльності послідовно проводив політику зміцнення господарств фермерського 
типу. Тільки з 1925 по 1931 р. включно він видав 17427 тис. злотих довгострокового кредиту на купівлю землі в Західній Україні, яким скористались 5455 міцних господарств, здебільшого польських колоністів, що купили 37970 га землі [6, арк. 6].

В роки економічної кризи погіршилося становище фермерських господарств, які неспроможні були сплачувати заборгованість та відсотки по кредитах. Відбулося значне зниженням цін на землю. Проте падіння ціни на землю відбувалося повільніше, ніж зниження ціни на сільськогосподарські продукти, а тому земля для селян ставала у 2-3 рази дорожчою, ніж напередодні кризи. Така тенденція на ринку цін була вкрай невигідна для незаможних селян і була доступна лише заможним верствам населення. Таким чином для незаможних земля на вільному ринку практично стала недоступною.

У березні 1932 р. були ухвалені два сеймові закони, один 3 яких стосувався захисту прав власників, котрі придбали малопридатні для обробітку грунти. Він передбачав їхній викуп за згодою власників за меншу вартість. Інший регулював право власності на землю. Адже близько 60\% набувачів парцел, заплативши попереднім власникам, не набули юридичного права власності на володіння ділянками, хоча фактично вільно розпоряджалися ними [23, s. 55-56].

Польським законодавством була унормована комасація, суть якої полягала в ліквідації багатосмужжя, тобто зведення розташованих у різних місцях земельних ділянок одного власника в єдину площу. Сеймова ухвала від 31 липня 1923 р. розв'язувала дану проблему при перерозподілі землі, що робило iï власника більш незалежним від громади та сприяло піднесенню культури господарювання і зростанню продуктивності праці. При цьому проведення комасації передбачало врегулювання інших важливих елементів землеустрою: ліквідацію сервітутів, поділ общинних земель, перегляд меж окремих територіальноадміністративних одиниць, виділення ділянок для спільного громадського користування, проведення меліорації тощо. Витрати, пов'язані зі складанням відповідної проектної документації, брали на себе власники господарств [25, с. 255].

Низка законодавчих актів мала врегулювати орендні відносини в аграрному секторі, що також сприяло його переходу 
на ринкові умови функціонування. Прийняті польським сеймом 28 серпня 1924 р. закон про захист дрібних орендарів та 18 березня 1932 р. закон про викуп земель дрібними орендарями формально впорядковували відносини в цій сфері[26, s. 35].

Реформування аграрного сектору, що проводився в Польщі у міжвоєнний період на східних окраїнах, мало колонізаційний характер починаючи від нормативно-правової бази і завершуючи iii реалізацією. Попри тенденцію щодо демократизації аграрного законодавства, у міжвоєнній Польщі приймалося й чимало актів, які більшою мірою захищали інтереси великих землевласників, аніж збіднілого селянства. Політика осадницької колонізації спричинила загострення земельної проблеми серед населення, що в свою чергу викликало загострення міжнаціональних відносин. Власне колонізаційний характер реформи визначив головну особливість ії здійснення у Західній Україні, - утиски українського селянства мали не лише економічний, але й національнополітичний характер.

1. Васюта I. Галицько-Волинське село між світовими війнами: Монографія / І. Васюта. - Львів: Каменяр, 2010. 507 с.; Зашкільняк Л. Історія Польщі: Від найдавніших часів до наших днів / Л. Зашкільняк, М. Крикун. - Львів : Львів. нац. ун-т ім. І. Франка, 2002. - 752 с.; Зуляк I. Особливості польської політики на західноукраїнських землях (1919-1939) / І. Зуляк // Наукові записки Тернопільського державного педагогічного університету ім. В. Гнатюка. Серія : Історія. - Тернопіль, 2002. - Вип. 3. C. 39-47; Комар B. Політика Польщі щодо українців Галичини (1919-1939 рр.) : основні напрямки та етапи / В. Комар // Галичина : науковий і культурно-просвітній краєзнавчий часопис. - Івано-Франківськ, 2001. - № 5-6. С. 290-295; Крюков А. Дослідження проблеми аграрної політики Польщі в Галичині в історичному аспекті / А. Крюков // Наукові записки Вінницького державного педагогічного університету імені Михайла Коцюбинського: зб. наук, праць. Серія : Історія. - Вінниця, 2014. - Вип. 22. C. $244-248$;

2. Borucki M. Historia Polski do 1957 roku / M. Borucki. Warszawa : Wydawnictwo naukowe PWN, 1998. - 364 s.; Wieczorkiewicz P. Ostatnie lata Polski niepodległej / P. Wieczorkiewicz. - Warszawa : Krajowa Agencja Wydawnicza, 1991. - 80 s.; Jezierski A. Historia Gospodarcza Polski / A. Jezierski, C. Leszczynska. - Warszawa : Key Text, 1999. 560 s.; Kaliński J. Landau Z. Gospodarka Polski w XX wieku / 
J. Kaliński, Z. Landau. - Warszawa : Polske Wydawnictwo Ekonomiczne, 2003. - 409 s.; Stobniak-Smogorzewska J. Kresowe osadnictwo wojskowe 1920-1945 / J. Stobniak-Smogorzewska. Warszawa: Instytut Studiow Politycznych PAN, oficyna wydawnicza RYTM, 2003. - 419 s.;Torzecki R. Kwestia ukraińska w Polsce w latach 1923-1929 / R. Torzecki. Kraków: Wydawnictwo Literackie, 1989. - 467 s.

3. Васюта I. Соціально-економічні відносини на селі Західної України до возз'єднання (1919-1939) / I. Васюта. Львів: Вища школа, 1978. - 192 с.

4. Виздрик В. Польське аграрне осадництво на західноукраїнських землях у 20-х рр. ХХ ст. / В. С. Виздрик // Грані. - 2013. - № 6. - С. 4-7.

5. Державний архів Львівської області, ф. 1, оп. 13, спр. 5.

6. Державний архів Івано-Франківської області, ф. 2 , оп. 9, спр. 480.

7. Жулканич Н. М. Методологія дослідження аграрних відносин в Україні (др. пол. ХХ ст.) / Н. М. Жулканич // Збірник навчально-методичних матеріалів та наукових статей історичного факультету ВНУ ім. Лесі Українки. К., 2008. - Вип. 14. - С. 215-221.

8. Зашкільняк Л. Історія Польщі: Від найдавніших часів до наших днів / Л. Зашкільняк, М. Крикун. - Львів: Львів. нац. ун-т ім. І. Франка, 2002. - 752 с.

9. Зуляк I. Особливості польської політики на західноукраїнських землях (1919-1939) / І. Зуляк // Наукові записки Тернопільського державного педагогічного університету ім. В. Гнатюка. Серія: Історія. - Тернопіль, 2002. Вип. 3. - С. 39-47.

10.Крамар Ю. Реалізація земельної реформи у Волинському воєводстві адміністрацією Г. Юзефського (1928-1938) / Ю. Крамар // Минуле і сучасне Волині. Олександр Цинкаловський і край : матеріали IX наук. іст. краєзн. міжнар. конф. - Луцьк, 1998. - С. 253-257.

11.Brzoza $C$ z. Polska w czasach niepodległości i II wojny światowej (1918-1945) / Cz. Brzoza. - Krakow, 2001. - 424 s.

12.Dabrowska $M$. O wykonaniu reformy rolnej (objasnienie ustawy z d. 15 lipca 1920 r. wraz z urzkdowym tekstem ustawy i przepisyw wykonawczych / M. Dąbrowska. Warszawa, 1921. - $36 \mathrm{~s}$.

13.Dziennik Ustaw Rzeczypospolitej Polskiej.Warszawa, 1920. - T.2, -1241s.

14.Dziennik Ustaw Rzeczypospolitej Polskiej.Warszawa, 1926. - T.1. 
15.Fialkowski $H$. Uporzadkowanie stanu prawnego drobnych gospodarstw na ziemiach wschodnich / H. Fialkowski. Lublin,1937. - $16 \mathrm{~s}$.

16.Jaworski W. Projekt kodeksu agrarnego / W.Jaworski Warszawa, 1928. - $427 \mathrm{~s}$.

17.Jaworski $W$. Reforma rolna. Tekst ustaw i rozporzadzen. - Krakow, 1926. - T. 3. - 346 s / W.Jaworski Warszawa, 1928. - $427 \mathrm{~s}$.

18. Ohanowicz A. Ustawa o wykonaniu reform rolney i inne ustawy rolne / A. Ohanowicz. - Poznan, 1926. - 504 s.

19. Reforma rolna w Polsce. - Warszawa,1929. - 169 s.

20. Rocznik ziem Wschodnich. - Warszawa, 1939. - 96 s.

21.Staniewicz W. O program agrarny w Polsce I jego wykonanie. Mowy i przemowienia (1926-1928) / Staniewicz.Warszawa,1928. - $139 \mathrm{~s}$.

22. Ustawa o wykonaniu reform rolnej // Dziennik Ustaw Rzeczypospolitej Polskiej. - 1920. - Nr. 70. - Poz. 462.

23. Wtudyka T. "Trzecia droga" w myśli gospodarczej II Rzeczypospolitej / T. Włudyk. - Kraków, 1994. - 169 s.

Надійшла до редколегії 10.09.2018 р.

\section{Vyzdryk V., Melnyk O. \\ SEVERSAL FEATURES COLONIZATION POLICY OF POLAND IN WESTERN UKRAINE DURING THE INTERWAR PERIOD: NORMATIVELY LEGAL BASE}

The article analyzes the normative and legal basis of the government agrarian policy of Poland in Western Ukraine during the interwar period.The subject is to study Polish agricultural colonization, which exacerbated the social and national contradictions between the Ukrainian and Polish population of the region. The planned sedentary colonization envisaged the relocation of military forces from the ethnic Polish lands andKey words: legal framework, interwar period, military sediments, civil colonists, Western Ukraine, colonization and the creation of their farms along the Polish-Soviet border, which were to become the social backbone of the government's policy on the eastern and south-eastern outskirts of Poland.

Keywords: normatively legal base, interwar period, military sediments, civil colonists, Western Ukraine, colonization. 